\title{
Histochemical changes induced by Trichoderma spp. and potassium phosphite in common bean (Phaseolus vulgaris) in response to the attack by Colletotrichum lindemuthianum
}

\section{Alterações histoquímicas induzidas por Trichoderma spp. e fosfito de potássio no feijoeiro (Phaseolus vulgaris) em resposta ao ataque de Colletotrichum lindemuthianum}

\author{
Eliana Peliçon Pereira Figueira ${ }^{1 *}$; Odair José Kuhn²; Tatiane Martinazzo-Portz ${ }^{1}$; \\ José Renato Stangarlin²; Marcos Donizete Peliçon Pereira ${ }^{3}$; Camila Lampugnani ${ }^{4}$
}

Highlights:

Histochemical techniques in the identification of structural changes in the bean plant. Application of phosphite-based formulations combined with biological inducers.

Resistance induction mediated by the formation of $\mathrm{H}_{2} \mathrm{O}_{2}, \mathrm{HR}$, and lignin deposition.

\begin{abstract}
Induction of resistance in common bean (Phaseolus vulgaris) has been considered a promising alternative to control anthracnose. Among the changes generated in the induction of resistance, structural changes have been reported by several authors as an efficient form of resistance to the stress plants undergo. Histochemical analysis techniques have been used to investigate tissue changes triggered by induction of resistance. Thus, this study aims to investigate certain histochemical changes suffered by common bean plants induced with potassium phosphite and Trichoderma spp. in response to the attack by Colletotrichum lindemuthianum, aiming to determine the host response pattern in terms of structural changes, associating it to possible disease control. Treatments consisted of isolates $T$. harzianum (isolate TOD1) and T. virens (isolate TM4), leaf fertilizer potassium phosphite Fertilis ${ }^{\circledR}$, and distilled water (control). Inducers were applied to common bean alone or associated, consisting of five treatments plus the control treatment. The six treatments were evaluated for the absence and presence of $C$. lindemuthianum in a factorial scheme $(6 \times 2)$. Treatments allowed evaluating the severity of anthracnose in common bean, location of $\mathrm{H}_{2} \mathrm{O}_{2}$, lignin deposition, and hypersensitivity response in common bean hypocotyl by histochemical staining. Potassium phosphite and combinations of $T$. virens and $T$. harzianum with potassium phosphite efficiently reduced disease severity under greenhouse conditions, reaching 68,84 , and $71 \%$, respectively. Studies with hypocotyl showed that $T$. harzianum + potassium phosphite and T. virens + potassium phosphite accelerated the $\mathrm{H}_{2} \mathrm{O}_{2}$ accumulation process and lignin deposition at the pathogen penetration site, in addition to the hypersensitivity reaction through the resistance-inducing activity, contributing to the protection of common bean against anthracnose caused by $C$. lindemuthianum.
\end{abstract}

Key words: Anthracnose. Hypersensitivity response. Induction of resistance. Oxygen-reactive species.

${ }^{1}$ Prof $^{\text {as }}$, Instituto Federal do Paraná, IFPR, Assis Chateaubriand, PR, Brasil. E-mail: eliana.figueira@ifpr.edu.br; tatiane.portz@ ifpr.edu.br.

2 Profs., Universidade Estadual do Oeste do Paraná, UNIOESTE, Marechal Cândido Rondon, PR, Brasil. E-mail: ojkuhn@gmail. com; jose.stangarlin@unioeste.br

3 Químico, Universidade Estadual Paulista Júlio de Mesquita Filho, UNESP, Araraquara, SP, Brazil. E-mail: mpelicon83@gmail.com

${ }^{4}$ Veterinária, IFPR, Assis Chateaubriand, PR, Brasil. E-mail: camila.lampugnani@ifpr.edu.br

"Author for correspondence 


\section{Resumo}

No cultivo do feijoeiro (Phaseolus vulgaris) a indução de resistência tem sido considerada uma alternativa promissora para o controle da antracnose. Dentre as alterações geradas na indução de resistência, as mudanças estruturais têm sido relatadas por diversos autores como uma forma eficiente de resistência ao estresse sofrido pela planta. Técnicas de análises histoquímicas têm sido utilizadas com o objetivo de investigar as alterações teciduais desencadeadas pela indução de resistência. Dessa forma, o presente trabalho tem por objetivo investigar determinadas alterações histoquímicas sofridas pelas plantas de feijoeiro induzidas com fosfito de potássio e Trichoderma spp. frente ao ataque de Colletotrichum lindemuthianum, visando determinar o padrão de resposta do hospedeiro em termos de modificações estruturais, associando esse padrão de resposta ao possível controle da doença. Os tratamentos consistiram de dois isolados: T. harzianum (isolado TOD1) e T. virens (isolado TM4), do fertilizante foliar Fosfito de Potássio Fertilis ${ }^{\circledR}$ e do tratamento com água destilada (controle). Os indutores foram aplicados no feijoeiro isoladamente ou combinados, constituindo cinco tratamentos mais o tratamento controle. Os seis tratamentos foram avaliados na ausência e presença de $C$. lindemuthianum em esquema fatorial $(6 \times 2)$. Mediante os tratamentos realizados, avaliou-se a severidade da antracnose no feijoeiro; localização de $\mathrm{H}_{2} \mathrm{O}_{2}$; deposição de lignina e resposta de hipersensibilidade em hipocótilo de feijoeiro por colorações histoquímicas. Em condições de casa de vegetação verificou-se que o fosfito de potássio e as combinações de Trichoderma virens e Trichoderma harzianum com fosfito de potássio reduziram de forma eficiente a severidade da doença, alcançando $68 \%, 84 \%$ e $71 \%$ respectivamente. Nos estudos com o hipocótilo, verificou-se que Trichoderma harzianum + fosfito de potássio e Trichoderma virens + fosfito de potássio, aceleram o processo de acúmulo de $\mathrm{H}_{2} \mathrm{O}_{2}$ e deposição de lignina no local de penetração do patógeno, e a reação de hipersensibilidade, mediante a atividade indução de resistência, contribuindo na proteção do feijoeiro à antracnose causada por $C$. lindemuthianum .

Palavras-chave: Antracnose. Resposta de hipersensibilidade (RH). Indução de resistência. Espécies reativas de oxigênio.

\section{Introduction}

Induction of resistance is a state of alert triggered by external agents that promote the activation of defense mechanisms in the plant (Stangarlin et al., 2011). Plants can respond to biotic or abiotic stresses through the induction of resistance (Borges \& Sandalio, 2015).

External agents that induce resistance in plants are classified as biotic or abiotic inducers, known to promote defense responses through structural and biochemical changes in the plant, involving mechanisms that culminate in strengthening the physical and mechanical resistance of the cell wall and production of enzymes and antimicrobial compounds (Niranjan Raj, Lavanya, Amruthesh, Niranjana, \& Reddy, 2012).

Biochemical and structural changes have been reported as an efficient form of resistance to the stress plants undergo. Several inducers are known to trigger induction of resistance through structural changes initiated by the activation of the hypersensitivity reaction (HR) at the penetration site, followed by other histological changes, such as papilla formation, lignification, callose, and cell wall thickening due to deposition of phenolic compounds and hydrogen peroxide (Niranjan Raj et al., 2012). These changes contribute to forming barriers that prevent pathogen penetration and/or colonization in the plant (Stangarlin et al., 2011).

Induction of resistance in common bean (Phaseolus vulgaris) has been an alternative to control anthracnose, a disease caused by the fungus Colletotrichum lindemuthianum (Sacc \& Magn), aiming to minimize the negative impact caused by agrochemicals in the environment, the main form to control this disease (Nozaki \& Kliemann, 2016; Pedro, Harakava, Lucon, \& Guzzo, 2012). 
Potassium phosphite has been described as an efficient resistance inducer in plants, and its efficiency has already been proven in the bean, papaya, apple, and coffee (Costa, Resende, Monteiro, Ribeiro, Botelho, \& Silva, 2017; Tavares et al., 2009; Araújo, Valdebenito-Sanhueza, \& Stadnik, 2010; Nojosa, Resende, Barguil, Moraes, \& Vilas Boas, 2009). However, other studies have focused on the use of biotic agents in inducing resistance. Fungi of the genus Trichoderma stand out because, in addition to acting as antagonists in the control of various phytopathogens, they also act as inducers of resistance in plants (Saba et al., 2012). Recent studies have demonstrated the success of Trichoderma spp. in the induction of resistance in tomatoes against Xanthomonas euvesicatoria and Alternaria solani (Fontenelle, Guzzo, Lucon, \& Harakava, 2011) and bean against Colletotrichum lindemuthianum (Pedro et al., 2012). Moreover, species of this genus favor the growth of tomato (Fontenelle et al., 2011) and bean (Pedro et al., 2012) through the incorporation to the substrate of rice medium colonized with Trichoderma.

Associating abiotic and biotic inducers may be a complementary way to induce resistance. Silva, Pinto, Nascimento, Silva and Souza (2019) obtained positive results with the association of potassium phosphite and $\operatorname{AgroMos}^{\circledR}$, which reduced the incidence of Elsinoe ampelina by $60.8 \%$ compared to the application of AgroMos ${ }^{\circledR}$ alone on grapes. The joint action of inducers may activate similar signaling pathways for both salicylic acid (SA) and jasmonic acid/ethylene (JA/ET) and contribute to potentiate the induction action.

Histochemical techniques have been used to evaluate changes induced in plants treated with different inducers, and recent studies have demonstrated the efficiency of these methods in identifying changes mediated by the induction of resistance in plant tissues. Niranjan Raj et al. (2012) used histochemical techniques to evaluate the induction of resistance in susceptible millet seedlings and observed the deposition of callose, lignin, and
$\mathrm{H}_{2} \mathrm{O}_{2}$ in the tissue of induced plants. Baldo et al. (2011) studied the leaf epidermis of bean treated with Pycnoporus sanguineus basidiocarp extracts and observed the presence of reactive oxygen species (ROS), characterizing it as one of the defense mechanisms against $C$. lindemuthianum. Freitas and Stadnik (2012) observed the hypersensitivity reaction in bean plants induced and inoculated with Colletotrichum lindemuthianum. Lignin deposition in plant tissues was also described by Southerton and Deverall (1990) in tissues from different resistant wheat strains inoculated with the leaf rust fungus Puccinia recondita f. sp. tritici. According to these authors, cell lignification plays a considerable role in the resistance of wheat cultivars, showing a direct relationship with plant sensitization.

Elucidating histochemical changes involved in a given interaction is of paramount importance for understanding the relationship between structural and biochemical mechanisms of the defense response, being of particular relevance when studying its importance relative to possible suppression of pathogens. In an attempt to address this aspect, we investigated histochemical changes in common bean plants induced with potassium phosphite and Trichoderma spp. in response to the attack by Colletotrichum lindemuthianum, aiming to determine the host response pattern in terms of structural changes, associating it to possible disease control.

\section{Material and Methods}

Obtaining and maintaining isolates of Trichoderma spp.

Isolates of Trichoderma spp. used in this study belong to the collection of the Laboratory of Phytopathology of Unioeste, Campus of Marechal Cândido Rondon. The isolates selected for this study consisted of Trichoderma harzianum (isolate TOD1) and Trichoderma virens (isolate TM4). These isolates were selected based on the results observed by Dildey (2014), being both isolates 
endophytic in bean roots and efficient in activating enzymes related to the induction of resistance against Colletotrichum lindemuthianum.

These isolates were maintained in Petri dishes with PDA (potato dextrose agar) medium at $28{ }^{\circ} \mathrm{C}$ and a 12 hour photoperiod until spore production. The concentration of the inoculum of Trichoderma spp. isolates used in bioassays was determined by quantifying the number of conidia. For this, spore count was performed using an Olympus CX31 light microscope and a Neubauer chamber. Inocula of Trichoderma spp. were added separately to the soil, and sand was used to grow the bean. The infestation was performed by adding $1 \mathrm{~mL}$ of inoculum suspension at a concentration of $1.0 \times 10^{9}$ conidia $\mathrm{mL}^{-1}$ at the time of sowing directly into the furrow.

\section{Obtaining and maintaining the inoculum of Colletotrichum lindemuthianum}

The fungus $C$. lindemuthianum race 73 used as a challenging pathogen was provided by EMBRAPACNPAF, Rice and Beans, Santo Antônio de Goiás, GO (Cl 1247-78, CNPAF-Embrapa).

Spores of the $C$. lindemuthianum race, used for inoculations, were obtained by cultivation in test tubes containing pod agar medium. Spore suspensions were prepared from fungus sporulation using sterile distilled water. The solution was adjusted to $1.0 \times 10^{6}$ conidia $\mathrm{mL}^{-1}$, and spore count was performed using an Olympus CX31 light microscope and a Neubauer chamber.

\section{Inducer treatment}

Treatments used to induce resistance in common bean against $C$. lindemuthianum consisted of three inducers, two biotic and one abiotic. Biotic inducers used were T. harzianum (isolate TOD1) and T. virens (isolate TM4), while the abiotic inducer was the leaf fertilizer potassium phosphite Fertilis ${ }^{\circledR}$. Treatments were applied alone and associated, consisting of five inducer treatments and a control treatment (distilled water), i.e., T. harzianum, T. virens, potassium phosphite, T. harzianum + potassium phosphite, $T$. virens + potassium phosphite, and sterile distilled water. In addition to receiving the six different treatments, plants were exposed to two conditions (absence and presence of the pathogen), generating a $6 \times 2$ factorial scheme.

Common bean seeds of the treatments $T$. virens and T. harzianum received $1 \mathrm{~mL}$ of conidial suspension at a concentration of $1.0 \times 10^{9}$ conidia $\mathrm{mL}^{-1}$, deposited directly in the soil furrows during sowing. On the other hand, common bean seeds of the treatment potassium phosphite were treated with a potassium phosphite solution at a concentration of $4 \mathrm{~mL} \mathrm{~L}^{-1}$, as recommended by the manufacturer. In addition to seed treatment, a leaf spraying of potassium phosphite at the same concentration described above was carried out at 18 days after sowing (just after the expansion of the second trifoliate leaf). Thus, treatments 3, 4, and 5 received potassium phosphite as seed treatment and leaf spraying.

\section{Disease severity evaluation}

Two experiments were carried out in a greenhouse at two different times to evaluate anthracnose severity. The first experiment was carried out between August and November 2015 and the second between May and July 2016. Both experiments were analyzed by joint analysis using the software SAS (Statistical Analysis System Institute [SAS Institute], 2014).

Seeds of common bean IPR Tangará were sown in $4 \mathrm{~L}$ cylindrical polypropylene pots filled with a substrate composed of soil, sand, and organic matter, at a proportion of $3: 2: 1$, autoclaved for one hour at $120^{\circ} \mathrm{C}$, repeating this operation after 24 hours. Three common bean seeds were sown in each pot.

The experiments were conducted using a randomized block design in a $6 \times 2$ factorial scheme, 
with six treatments and two conditions, distributed in five blocks, totaling 60 experimental plots, each pot being considered a plot.

Plants grown in pots received the treatments, with the pathogen inoculated 72 hours after leaf spraying with potassium phosphite. Spore suspension adjusted to $1.0 \times 10^{6}$ conidia $\mathrm{mL}^{-1}$ was applied by leaf spraying on common bean plants until the entire leaf wetting. After inoculation, the common bean plants were maintained in a humid chamber for 24 hours and at a temperature of approximately $22{ }^{\circ} \mathrm{C}$ (Dalla Pria, Amorim, \& Bergamin, 2003), followed by room temperature. The plants remained in a greenhouse for further analysis.

Disease severity evaluation started on the fourth day after inoculation, using the diagrammatic scale developed by Dalla Pria, Amorim and Canteri (1999) and performed with a three-day interval for fifteen days, totaling five evaluations.

The percentages of the injured area were used to draw the disease progress curve and calculate the area under the disease progress curve (AUDPC), according to the adapted equation by Shaner and Finney (1977), where AUDPC $=\sum\left[\left(\frac{Y 1+Y 2+1}{2}\right) \times\left(T_{2}-T_{1}\right)\right]$, in which $Y 1$ and $Y 2$ represent two consecutive evaluations of severity (proportion of disease) performed at times $\mathrm{T} 1$ and $\mathrm{T} 2$, respectively.

\section{Histochemical analyses of induction of resistance}

Histochemical analyses were performed in the common bean hypocotyl, grown in previously disinfected plastic trays filled with autoclaved sand. Twenty common bean seeds of the cultivar IPR Tangará were sown in each tray, with two trays for each treatment. In this case, there was no leaf spraying with potassium phosphite, as in the plants grown in pots. Therefore, potassium phosphite was added only to the seeds through the already mentioned treatment. Seeds of the cultivar IPR-Tangará were treated with the same treatments carried out for common bean grown in pots, but only the control treatment was exposed to both conditions, i.e., presence and absence of the pathogen. The other treatments were conditioned only to the presence of the pathogen.

The pathogen was inoculated after the beginning of hypocotyl elongation when it protruded from the surface layer of sand. For that, the spore suspension adjusted to $1.0 \times 10^{6}$ conidia $\mathrm{mL}^{-1}$ was applied by spraying under the hypocotyls using a spray bottle. Spraying was performed uniformly throughout the hypocotyl. After pathogen inoculation, the trays containing the hypocotyls were maintained in a humid chamber for 24 hours at a temperature of approximately $22{ }^{\circ} \mathrm{C}$ (Dalla Pria et al., 2003). Subsequently, they were maintained at room temperature for collection and subsequent histochemical staining.

Collections were performed at times 0,12 , $24,48,72,96,120$, and 144 hours after pathogen inoculation by observing the sequence of morphological changes in the cells under the microdrop of conidial suspension using histochemical techniques and analyzing them using an Olympus CX31 light microscope. The images were captured using Biotika 5.0 camera using the software ISCapture.

\section{Location of in situ $\mathrm{H}_{2} \mathrm{O}_{2}$}

Hypocotyl portions, treated and cultivated as described above, were immersed in a solution containing $1 \mathrm{mg} \mathrm{mL} \mathrm{m}^{-1}$ of 3,3'-diaminobenzidine (DAB) in distilled water and $\mathrm{pH}$ adjusted to 5.6 with $\mathrm{KOH}$. They remained exposed to infiltration for one hour using a vacuum pump (90 $\mathrm{mm} \mathrm{Hg}$ ). Subsequently, they were clarified in $96 \%$ alcohol and mounted in $50 \%$ glycerin. Cells that showed $\mathrm{H}_{2} \mathrm{O}_{2}$ accumulation had brown staining (ThordalChristensen, Zhang, Wei, \& Collinge, 1997) and were analyzed using an Olympus CX31 light microscope. Images were captured using a Biotika 5.0 camera. Twenty microscopic fields were evaluated per treatment at each collection time. 


\section{Lignin deposition}

The hypocotyls extracted in each of the treatments and at times mentioned above were fixed in FAA (formalin-acetic acid-50\% alcohol, 5:5:90, v/v/v), washed in $70 \%$ alcohol, and stored in a refrigerator for later histochemical staining. Hypocotyl portions were soaked in a $2 \%$ phloroglucinol solution in $95 \%$ ethanol for 2 hours to observe lignin deposition (Niranjan Raj et al., 2012). After this period, a drop of $35 \% \mathrm{HCl}$ was added and heated over a low flame until the ribs reached a red-purple color. Cells were observed under an Olympus CX31 light microscope and monitored for staining intensity. Twenty microscopic fields were evaluated per treatment.

\section{Occurrence of hypersensitivity response (HR)}

Epidermal portions of the common bean hypocotyl, treated and cultivated in plastic trays filled with sand, were collected at times already mentioned, being evaluated the occurrence of HR by the presence of necrotic spots and observation of dead cells (Niranjan Raj et al., 2012). Small epidermal portions of the hypocotyl were immersed in a $0.2 \%$ neutral red solution prepared by the dissolution in $0.1 \mathrm{M}$ potassium phosphate buffer ( $\mathrm{pH}$ 7.6) containing $0.5 \mathrm{M}$ sucrose. These portions received the dye and were observed under a light microscope after 10 minutes (Kumudini, Vasanthi, $\&$ Shetty, 2001). In this type of staining, cells that show plasmolysis are considered viable cells, and those that do not accumulate dye in the vacuole or accumulate it in the cytoplasm, without any osmotic changes, are considered dead. Images were captured using a Biotika 5.0 camera. Twenty microscopic fields were evaluated per treatment.

\section{Results and Discussion}

\section{Anthracnose severity}

The means of AUDPC and final severity, obtained in both experiments, were subjected to joint analysis, with results shown in Table 1. Anthracnose severity in common beans was significant for all treatments, reducing the means of AUDPC and final severity, differing statistically from the control treatment.

Among treatments, the lowest mean of AUDPC was observed for $T$. virens + potassium phosphite, followed by potassium phosphite and T. harzianum + potassium phosphite, reducing disease severity by $84.53,71.42$, and $68.53 \%$, respectively. Also, the treatment $T$. virens + potassium phosphite differed from the means of AUDPC obtained for treatments in which $T$. virens and T. harzianum were applied alone.

\section{Table 1}

Area under the disease progress curve (AUDPC) and final severity (\% of injured leaf area) of anthracnose in common bean grown in a greenhouse and treated with Trichoderma harzianum (TOD1), Trichoderma virens (TM4), potassium phosphite, Trichoderma harzianum + potassium phosphite, Trichoderma virens + potassium phosphite, and water (control)

\begin{tabular}{lcc}
\hline Treatment & AUDCP & Final severity (\%) \\
\hline T. harzianum & $30.35 \mathrm{~b}$ & $3.51 \mathrm{~b}$ \\
T. virens & $23.99 \mathrm{bc}$ & $2.71 \mathrm{~b}$ \\
Potassium phosphite & $15.15 \mathrm{~cd}$ & $1.90 \mathrm{bc}$ \\
T. harzianum + potassium phosphite & $18.68 \mathrm{bcd}$ & $1.98 \mathrm{bc}$ \\
T. virens + potassium phosphite & $8.20 \mathrm{~d}$ & $0.93 \mathrm{c}$ \\
Control & $53.00 \mathrm{a}$ & $5.75 \mathrm{a}$ \\
\hline Overall mean & 24.89 & 2.80 \\
CV $(\%)$ & 38.03 & 46.63 \\
\hline
\end{tabular}

The data in the table correspond to the joint analysis of two experiments.

Means followed by the same letter in the column do not differ from each other by the Tukey test at a $5 \%$ significance. 
Several authors have reported the use of Trichoderma spp. as an excellent inducer of plant resistance to phytopathogens. Pedro et al. (2012) used T. harzianum, T. strigosum, and T. theobromicola and obtained efficiency in protecting bean against anthracnose, caused by $C$. lindemuthianum, observing a reduction of up to $97.54 \%$ in disease severity.

The use of Trichoderma spp. alone, although it has reduced disease severity, was not the most efficient treatment compared to the others. This difference may be related to the capacity that certain Trichoderma spp. isolates have to establish an association with the plant and activate its defense mechanisms. Walters, Ratsep and Havis (2013) attributed the resistance-inducing effect by Trichoderma spp. as a genotype-dependent trait from both the crop and Trichoderma isolates. Singh, Shukla, Kabadwal, Tewari and Kumar (2018) stated that Trichoderma spp. establishes chemical and systemic communication when colonizing bean roots, being able to activate metabolic pathways, such as salicylic acid (SA) and jasmonic acid/ ethylene (JA/ET), from the induction of systemic resistance. Thus, there is a cross-communication between SA, JA/ET, and some plant hormones that induce different responses depending on the elicitor characteristics.

Although the use of potassium phosphite as treatment did not present the lowest mean of AUDPC, it promoted a reduction in disease severity alone $(71.42 \%)$ and associated with Trichoderma spp. isolates. Gadaga, Abreu, Resende and Ribeiro (2017) used potassium and manganese phosphite and obtained the lowest mean in the area under the anthracnose progress curve in bean plants. J. L. Silva et al. (2015) reported that potassium phosphite reduced anthracnose severity by $60.4 \%$ in common beans, as well as mycelial growth inhibition and germ tube emission of $C$. lindemuthianum by its direct action. Costa et al. (2017) found similar results with potassium phosphite formulations, which reduced anthracnose severity by $55.6 \%$ in common bean. In this same study, the authors detected the presence of phosphite residues in leaf tissues at concentrations of 1 and $3 \mathrm{mM}$ at seven days after spraying. However, they did not combine the application of phosphite-based formulations with biological treatments.

Although complex and still little known, several studies have suggested two mechanisms of action of phosphite: directly on the pathogen by inhibiting its growth as a result of phosphite accumulated in the plant tissue, and indirectly by inducing resistance in plants (Costa et al., 2017). Phosphite application in plants is associated with several mechanisms, such as increased transcription of genes involved in the SA and JA/ET signaling pathways (Eshraghi et al., 2011), activation of defense proteins, accumulation of phytoalexins (Melo, Araújo, Serra, \& Pascholati, 2017; Gómez-Merino \& Trejo-Téllez, 2015), inhibitors of pathogen hydrolases, and even the strengthening of natural tissue barriers by increasing of lignin synthesis (Eshraghi et al., 2011).

On the other hand, potassium phosphite is a molecule derived from the union of two compounds, and potassium can also positively interfere with induction. Dordas (2008) pointed out that potassium supply in plants could lead to increased plant resistance to disease, which has been attributed to several mechanisms of action of potassium, such as its activity as an enzymatic cofactor, in the synthesis of proteins, and in decreasing cell permeability.

Thus, the results obtained in this study show that the association of Trichoderma isolate (TM4) with potassium phosphite led to more efficient control of anthracnose in common beans, reducing, on average, by $84.53 \%$ disease severity. This association of inducers may have led to an additive effect, increasing plant response to phytopathogens and reducing disease severity in common bean. This additive effect may have been achieved by the various forms of control provided by the used inducers, either by direct action through the residual 
accumulation of potassium phosphite in plant tissues or by the modulation between signaling pathways dependent on SA or JA/ET of both inducers, which would generate a rapid and intense response.

\section{Histochemical changes of induction of resistance}

Location of in situ $\mathrm{H}_{2} \mathrm{O}_{2}$

Groups of cells containing $\mathrm{H}_{2} \mathrm{O}_{2}$ deposition for some of the tested treatments were verified through the DAB (3,3'-diaminobenzidine) staining technique in the histochemical analyses carried out on epidermal portions of the hypocotyl. These groups of cells showed a dark yellow color, mainly in cells where fungus hyphae were associated (Figure 1).

The treatment $T$. harzianum + potassium phosphite showed reactions from 24 hours after pathogen inoculation, being located in epidermal cells around the stomata (Figure 1A and B). The deposition of a considerable number of spores not yet germinated occurred in sites where the reaction was observed, showing the celerity with which the plant reacted from the moment it actually came into contact with the host.
Other treatments showed reactions at different times. Hypocotyls that received the treatment $T$. virens + potassium phosphite showed a reaction 48 hours after pathogen inoculation (Figure 1C), while T. virens + potassium phosphite showed reactions 96 hours after pathogen inoculation. The control treatment and T. harzianum treatment showed no reaction at the analyzed times. Thus, the treatments T. harzianum + potassium phosphite and T. virens + potassium phosphite had a rapid $\mathrm{H}_{2} \mathrm{O}_{2}$ deposition in the epidermal tissue of the bean hypocotyl.

Therefore, the formation of reactive oxygen species (ROS), represented by $\mathrm{H}_{2} \mathrm{O}_{2}$ deposition in the tissue, may have contributed to reduce anthracnose severity because both treatments in which there were rapid expression and previous $\mathrm{H}_{2} \mathrm{O}_{2}$ accumulation in the tissue showed reductions in the means of AUDPC, with a consequent reduction in severity (Table 1). This reduction is possibly related to the fact that ROS production is often a very rapid and intense response (oxidative explosion), which may occur within minutes after contact with the pathogen or several hours after the initial stage of infection or treatment with elicitors. ROS release hours after the initial contact is characterized as a secondary oxidative explosion, being stronger and prolonged and directly related to the induction of plant resistance to the pathogen (Gill \& Tuteja, 2010; Stangarlin et al., 2011). 


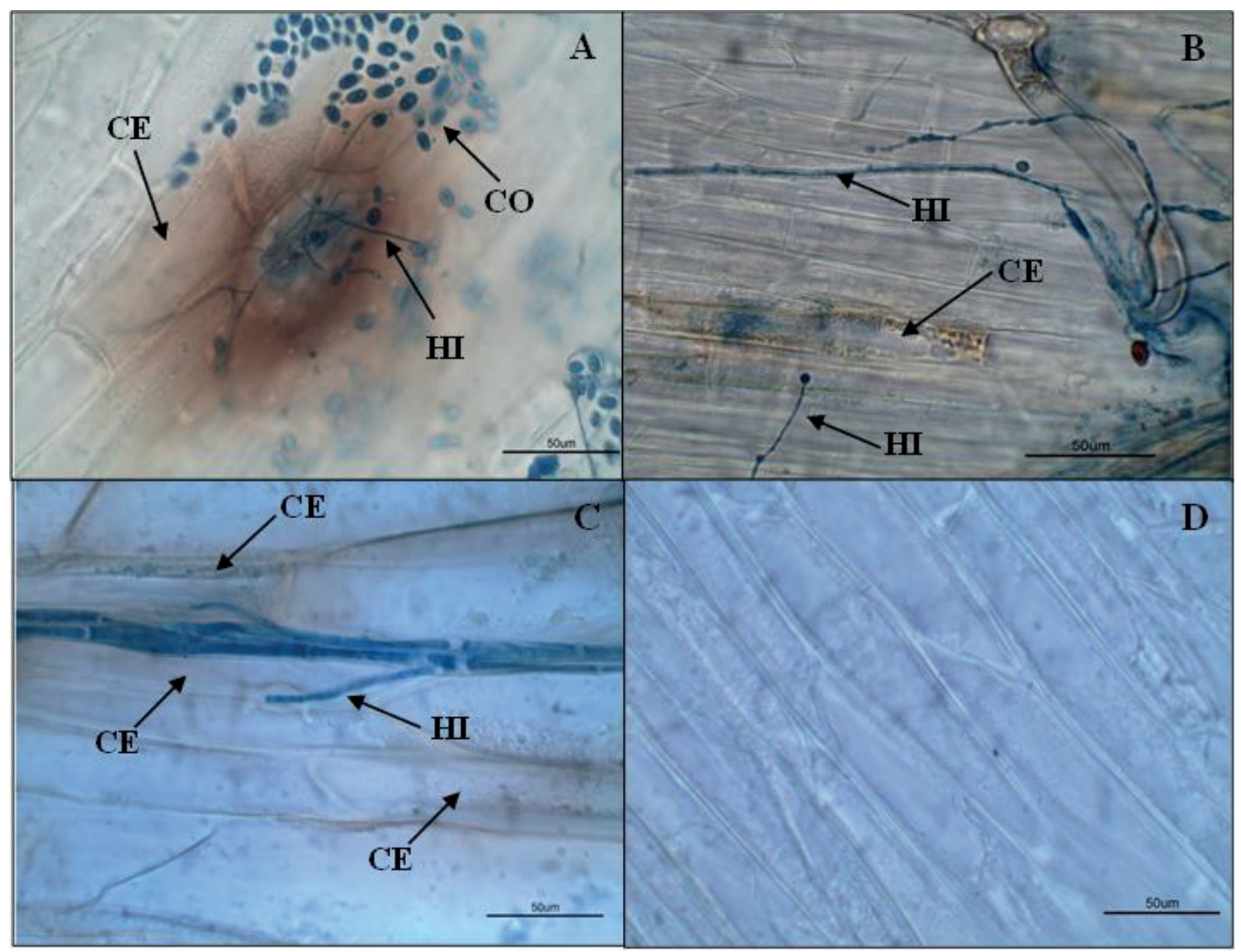

Figure 1. Location of $\mathrm{H}_{2} \mathrm{O}_{2}$ in situ in the Phaseolus vulgaris hypocotyl treated with Trichoderma harzianum + potassium phosphite and Trichoderma virens + potassium phosphite inoculated with Colletotrichum lindemuthianum.

A: Photomicrograph of hypocotyl epidermal cells of common bean treated with Trichoderma harzianum + potassium phosphite, with $\mathrm{H}_{2} \mathrm{O}_{2}$ detection at 24 hours after pathogen inoculation. B: Photomicrograph of hypocotyl epidermal cells of common bean treated with Trichoderma harzianum + potassium phosphite, with $\mathrm{H}_{2} \mathrm{O}_{2}$ detection at 48 hours after pathogen inoculation. C: Photomicrograph of hypocotyl epidermal cells of common bean treated with Trichoderma virens + potassium phosphite, with $\mathrm{H}_{2} \mathrm{O}_{2}$ detection at 48 hours after pathogen inoculation. D: Photomicrograph of hypocotyl epidermal cells of the control common bean. CO: Colletotrichum lindemuthianum conidium; HI: Colletotrichum lindemuthianum hypha; ET: stoma; CE: epidermal cell showing $\mathrm{H}_{2} \mathrm{O}_{2}$ reaction. Hyphae and conidia were stained with lactophenol cotton blue.

Thus, ROS can cause oxidative damage and compromise cell integrity, acting directly on the pathogen and inhibiting its development (Niranjan Raj et al., 2012; Sewelam, Kazan, \& Schenk, 2016). In addition to its direct action on pathogens, ROS can mediate different defense mechanisms in the plant, including strengthening of the cell wall through changes in the cross-bonds between hydroxyprolinerich glycoproteins (involved in the strengthening of the cell wall) and induction of programmed cell death in infected regions (HR) to restrict pathogen invasion and activation of signaling pathways that regulate the production of defense compounds, such as the SA and JA/ET pathway (Jwa \& Hwang, 2017; Zurbriggen, Carrillo, \& Hajirezaei, 2010).

Several authors have reported the occurrence of rapid response of $\mathrm{H}_{2} \mathrm{O}_{2}$ production in plants. Niranjan Raj et al. (2012) studied millet coleoptile 
induced by Bacillus pumilus and observed that the reaction with DAB occurred 12 hours after Sclerospora graminicola inoculation, with a clear $\mathrm{H}_{2} \mathrm{O}_{2}$ deposition in the epidermal tissue of millet plants. According to the authors, this rapid response with ROS production allowed a high resistance of millet plants induced by B. pumilus, presenting a pattern very similar to resistant cultivars.

In common bean, studies using the same technique have reported a faster $\mathrm{H}_{2} \mathrm{O}_{2}$ occurrence in the plant tissue by inducing resistance. Baldo et al. (2011) studied leaf epidermis and observed the presence of $\mathrm{H}_{2} \mathrm{O}_{2}$ at 48 hours after $C$. lindemuthianum inoculation in bean plants treated with Pycnoporus sanguineus basidiocarp extracts. The authors also attributed the reduction in disease severity to ROS deposition in the plant tissue.

The difference in time observed for ROS deposition in the various studies mentioned above is possibly due to the type of pathosystem and used inducer, in which many variable conditions may be associated. Also, Bashir et al. (2013) stated that in most pathosystems, infection by pathogens is nonsynchronous, which makes it difficult to arrange the cytological events involved in different treatments chronologically.

\section{Lignin deposition}

The evaluations for detecting lignin in epidermal tissues of the bean hypocotyl using the phloroglucinol staining technique showed regions with a reddish-brown color (Figure 2). At these sites, the lignin deposited inside the cells reacted with phloroglucinol to form this characteristic color.

Thus, bean hypocotyls that received the treatment T. virens + potassium phosphite had an initial histochemical reaction at 48 hours after pathogen inoculation. Lignin deposition was identified for the treatments T. harzianum + potassium phosphite, potassium phosphite, and $T$. virens at 72 hours after pathogen inoculation, while for T. harzianum and the control treatment, it was observed at 96 hours after pathogen inoculation (Figure 2).

The treatment $T$. virens + potassium phosphite had the highest deposition rate, occurring before the other treatments, including the control. Thus, lignin deposition associated with reactive oxygen species production may have acted as limiting factors, contributing to disease reducing, as the treatment $T$. virens + potassium phosphite had the lowest mean of AUDPC. In addition, the deposition of these compounds occurred even before the germination of most $C$. lindemuthianum spores in the epidermal tissue (Figure 2F and G). 


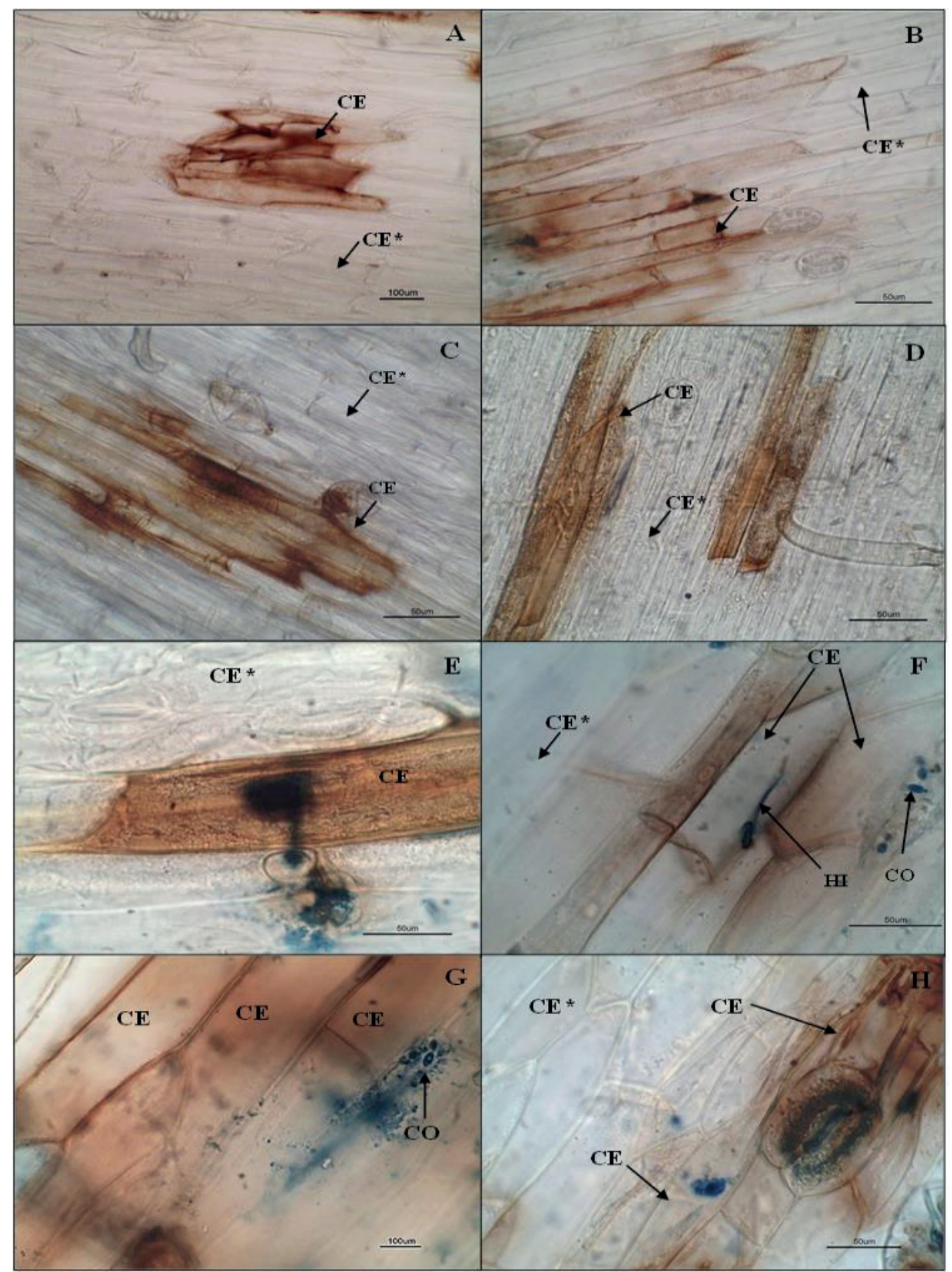

Figure 2. Lignin deposition in the hypocotyl epidermis of Phaseolus vulgaris treated with different inducers and inoculated with $C$. lindemuthianum.

A: control - 96 hours after pathogen inoculation. B: Trichoderma harzianum - 96 hours after pathogen inoculation. C: potassium phosphite - 72 hours after pathogen inoculation. D: Trichoderma virens 72 hours after pathogen inoculation. E and F: Trichoderma harzianum + potassium phosphite -72 hours after pathogen inoculation. $\mathbf{G}$ and $\mathbf{H}$ : Trichoderma virens + potassium phosphite - 48 hours after pathogen inoculation. $\mathrm{CE}^{*}$ : epidermal cell; CE: epidermal cell with lignin deposition. Hyphae and conidia were stained with lactophenol cotton blue. 
Similarly, Niranjan Raj et al. (2012) studied the millet coleoptile. They observed lignin depositions in the plant tissue at 12 and 24 hours after pathogen inoculation for resistant and susceptible cultivar, respectively, allowing a high efficiency in the resistance of millet plants induced by Bacillus pumilus. The authors also correlated the increased lignin with pathogen control. Southerton and Deverall (1990) used histochemical techniques and observed lignin deposition in tissues of different wheat lines inoculated with Puccinia recondita f. sp. tritici, the causal agent of leaf rust. Although the authors did not analyze the induction of resistance, they stated that the lignification in wheat tissues could play a considerable role in the resistance of cultivars to the fungus that causes rust in wheat, showing a direct relationship with plant sensitization.

According to Baxter and Stewart (2013), cell walls around wounds can receive the deposition of substances such as lignin, suberin, and/or phenolic acids. These deposits provide an increase in the wall resistance to the action of degrading enzymes, preventing the diffusion of toxins from the pathogen towards the host or nutrients from the host plant towards the pathogen, restricting pathogen colonization. In this sense, organs with less lignification tend to be more susceptible during infection by C. lindemuthianum (Cruz, Araujo, Polanco, \& Rodrigues, 2014).

According to Stangarlin et al. (2010), the lignification of a cell or part of the tissue makes walls more resistant to penetration and can result in the lignification of the pathogen hyphae, isolating it from the host and hindering the transit of water and nutrients from the host to the fungus and toxins and enzymes from the pathogen to the host. L. M. Silva, Alquini and Cavallet (2005) stated that lignin deposition inside plant tissues is an anatomical characteristic resulting from the plant defense mechanism.

\section{Hypersensitivity response}

Hypersensitivity response was evaluated by analyzing the plasmolysis reaction of epidermal cells of the common bean hypocotyl immersed in a $0.2 \%$ neutral red solution prepared by the dissolution in $0.1 \mathrm{M}$ potassium phosphate buffer (pH 7.6) containing $0.5 \mathrm{M}$ sucrose.

Because it is a vital dye, neutral red in solution is accumulated in the vacuole of viable cells. In this staining, besides the accumulation of neutral red in the vacuole, there is also a plasmolysis reaction because the solution has a high sucrose concentration. Thus, plasma membrane retracts and distances from the cell wall, approaching the vacuole tonoplast, with the formation of a red vesicle, a characteristic reaction of healthy tissues (Figures 3).

According to O'Connell, Bailey and Richmond (1985), the loss of capacity of the tonoplast to contract and the neutral red to accumulate in the vacuole is considered as indicative of cell death. Thus, cells killed by HR show no plasmolysis, and neutral red is not accumulated in the vacuole.

Two patterns of cells were observed in HR: one in which cells showed no plasmolysis and accumulated no neutral red in the vacuole, and another in which cells showed no plasmolysis, but presented an intense red (Figure 4). Similarly, O'Connell et al. (1985) also observed cells in a hypersensitivity reaction with no staining and those that stained strongly red, both without the occurrence of plasmolysis. According to the authors, the occurrence of cells with a dark red color is a result of the reaction of neutral red with some type of phenolic compound accumulated in the cell. 


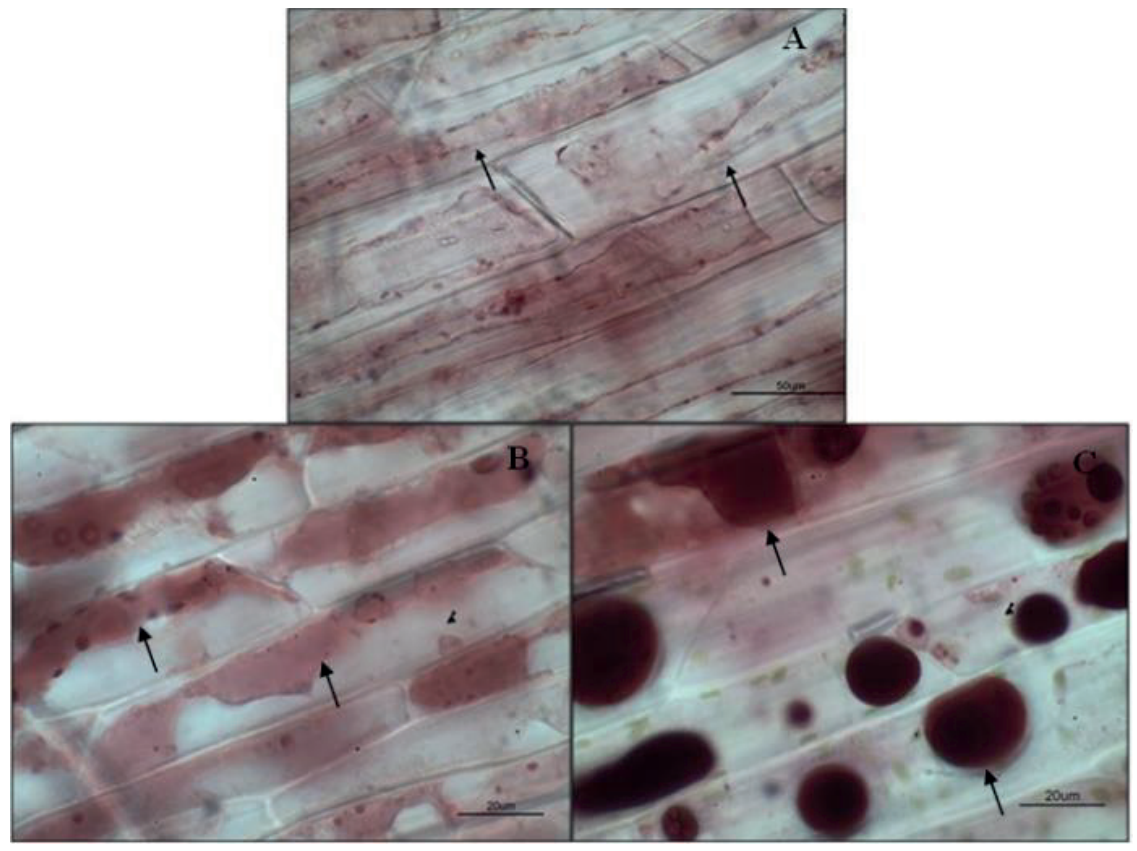

Figure 3. Hypocotyl epidermal cells of Phaseolus vulgaris under the control treatment in the absence of Colletotrichum lindemuthianum, showing the response of the healthy tissue to staining with neutral red in potassium phosphate buffer (pH 7.6) and sucrose.

A: portion of the epidermis 5 minutes after immersion in neutral red solution, showing cells in initial plasmolysis. B: portion of the epidermis 7 minutes after receiving the dye solution, showing the progress of the plasmolysis process. $\mathbf{C}$ : portion of the control epidermis 10 minutes after receiving the dye solution. The arrow indicates the retraction of the plasma membrane with the cell content of some of the cells underwent plasmolysis.

Thus, HR was only observed in treatments in which inducers were associated, starting at 48 hours after pathogen inoculation. Moreover, cells in HR that showed intense red staining had a disorganized cytoplasm, with an irregular dye distribution.

Several studies have already been carried out, showing HR in plants treated with inducers. In this sense, most of the analyzed millet coleoptiles treated with the inducer Bacillus pumilus INR-7 showed HR at 24 hours after pathogen inoculation, unlike that observed for the disease-resistant millet, in which HR was observed before 12 hours after Sclerospora graminicola inoculation (Niranjan Raj et al., 2012).

Bean leaves treated with the inducer Ulvana showed hypersensitivity reaction at 48 hours after Colletotrichum lindemuthianum inoculation (Freitas
\& Stadnik, 2012). The authors reported it as the first time that a hypersensitivity response has occurred in a bean cultivar highly susceptible to a compatible C. lindemuthianum race.

Thus, hypersensitivity response consists of the formation of chemical barriers occurring at the point of pathogen penetration and involves successive events and signals that range from the recognition between the pathogen and the host to the localized plant cell collapse, preventing the development of pathogen infection, corresponding to the first stage of the plant defense response (Niranjan Raj et al., 2012). According to Costa et al. (2017), infected cells after phosphite treatment undergo rapid changes that include cell death by HR, activation of defense-related biosynthetic pathways, which can accumulate high levels of phytoalexins, and deposition of physical barriers around infected cells. 


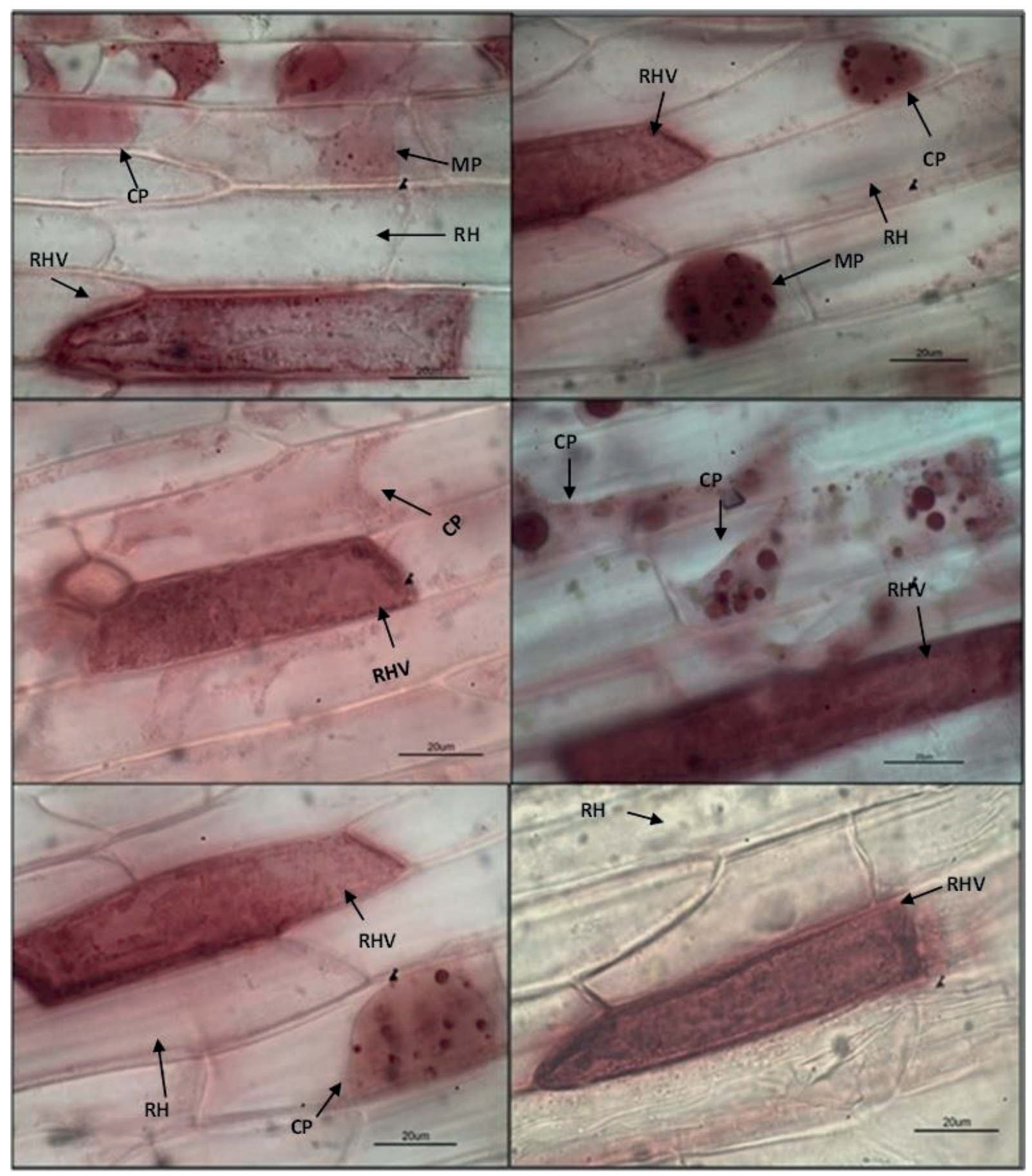

Figure 4. Hypersensitivity response in hypocotyl epidermal cells of Phaseolus vulgaris treated with different inducers and inoculated with Colletotrichum lindemuthianum. Images show portions of the epidermis stained with the neutral red solution. Images show epidermal cells with three types of responses observed for treatments with Trichoderma harzianum + potassium phosphite and T. virens + potassium phosphite.

CP: live plasmolyzed cells (without the occurrence of hypersensitivity response); RH: cells in HR that did not plasmolyze and did not retain the dye; RHV: cells that did not plasmolyze, but stained strongly red due to the presence of phenolic compounds. RHVs have disorganized cytoplasm with an irregular dye distribution. MP: plasma membrane; PC: cell wall. 
In the present study, although the reported histochemical changes were presented separately, each induction of resistance event treated here acts synchronically. Thus, one of the first defense responses observed here was $\mathrm{H}_{2} \mathrm{O}_{2}$ deposition, followed by HR, and lignin deposition in hypocotyl tissues. These results corroborate the description of Soares and Machado (2007), who stated that one of the first responses observed in plants attacked by pathogens is an increase in ROS production (oxidative explosion). Because ROS play a fundamental role in cell signaling pathways during pathogen perception (Sewelam et al., 2016), the rapid $\mathrm{H}_{2} \mathrm{O}_{2}$ production observed in this study may have been essential for the expression of defense genes related to HR and lignification of tissues around the points of contact between pathogen hyphae and epidermal cells.

Therefore, the results observed here suggest a pattern of responses in which the interaction between potassium phosphite and Trichoderma spp. may have triggered the rapid generation of $\mathrm{H}_{2} \mathrm{O}_{2}$, lignin, and HR, which may have culminated in the reduction of anthracnose severity in common bean.

Considering that the response of $\mathrm{H}_{2} \mathrm{O}_{2}$ and lignin deposition was late in the treatment with potassium phosphite alone compared to treatments in which potassium phosphite was associated, we can suggest that a mean severity reduction of $71.4 \%$ may also be related to the ability to act directly on the pathogen. It confirms the findings of Costa et al. (2017), who highlighted the capacity of phosphite to accumulate in the plant tissue and act directly on the pathogen. According to these authors, the treatment with phosphite led to anthracnose control in common bean in two ways, i.e., acting directly on C. lindemuthianum and inducing defense responses in the plant, which may also have occurred in the present study.

Thus, our results show that treatments in which Trichoderma spp. and potassium phosphite were associated presented resistance-inducing activity, possibly mediated by $\mathrm{H}_{2} \mathrm{O}_{2}$ formation, $\mathrm{HR}$, and lignin deposition, contributing to the protection of common bean against anthracnose caused by $C$. lindemuthianum.

\section{Acknowledgments}

To the Graduate Program in Agronomy at the State University of Western Paraná, campus of Marechal Cândido Rondon. To CAPES for supporting the graduate program through PROAP.

To IFPR for the possibility of leaving teaching activities and availability of using the institutional facilities.

\section{References}

Araújo, L., Valdebenito-Sanhueza, R. M., \& Stadnik, M. J. (2010). Avaliação de formulações de fosfito de potássio sobre Colletotrichum gloeosporioides in vitro e no controle pós-infeccional da mancha foliar de Glomerella em macieira. Tropical Plant Pathology, 35(1), 54-59. doi: 10.1590/S198256762010000100010

Baldo, M., Stangarlin, J. R., Franzener, G., Assi, L., Kuhn, O. J., \& Schwan-Estrada, K. R. F. (2011). Detecção in situ de espécies reativas de oxigênio em feijoeiro tratado com extratos de Pycnoporus sanguineus e inoculado com Colletotrichum lindemuthianum. Summa Phytopathologica, 37(4), 174-179. doi: 10.1590/S0100-54052011000400002

Bashir, Z., Ahmad, A., Shafique, S., Anjum, T., Shafique, S., \& Akram, W. (2013). Hypersensitive response A biophysical phenomenon of producers. European Journal of Microbiology and Immunology, 3(2), 105-110. doi: 10.1556/EuJMI.3.2013.2.3

Baxter, H. L., \& Stewart, C. N. (2013). Effects of altered lignin biosynthesis on phenylpropanoid metabolism and plant stress. Biofuels, 4(6), 635-650. doi: $10.4155 / \mathrm{bfs} .13 .56$

Borges, A. A., \& Sandalio, L. S. (2015). Induced resistance for plant defense. Frontiers in Plant Science, 6(109), 109-124. doi: 10.3389/fpls.2015.00109

Costa, B. H. G., Resende, M. L. V., Monteiro, A. C. A., Ribeiro, P. M. Jr., Botelho, D. M. S., \& Silva, B. M. (2017). Potassium phosphites in the protection of common bean plants against anthracnose and biochemical defence responses. Journal of Phytopathology, 166(2), 1-8. doi: 10.1111/jph.12665 
Cruz, M. F. A., Araujo, L., Polanco, L. R. \& Rodrigues, F. A. (2014). Aspectos microscópicos da interação feijoeiro Colletotrichum lindemuthianum mediados pelo silício. Bragantia, 73(3), 284-291. doi: 10.1590/1678-4499.0139

Dalla Pria, M., Amorim, L., \& Bergamin, A., Filho. (2003). Quantificação de componentes monocíclicos da antracnose do feijoeiro. Fitopatologia Brasileira, 28(4), 401-407, 2003. doi: 10.1590/S010041582003000400009

Dalla Pria, M., Amorin, L., \& Canteri, M. G. (1999). Métodos de avaliação das doenças. In: Canteri, M. G., Dalla Pria, M., \& Silva, O. C. Principais doenças fúngicas do feijoeiro (pp. 53-64). Ponta Grossa: UEPG.

Dildey, O. D. F. (2014). Interação Trichoderma-feijoeiro e seus efeitos na fisiologia e indução de resistência contra antracnose (Colletotrichum lindemuthianum). Dissertação de mestrado, Universidade Estadual do Oeste do Paraná, Marechal Candido Rondon, PR, Brasil. Recuperado de http://tede.unioeste.br/

Dordas, C. (2008). Role of nutrients in controlling plant diseases in sustainable agriculture. A review. Agronomy for Sustainable Development, 28(1), 33-46. doi: 10.1051/agro:2007051

Eshraghi, L., Anderson, J., Aryamanesh, N., Shearer, B., Mccomb, J., G. E., Hardya, S. J., \& O’briena, P. A. (2011). Phosphite primed defence responses and enhanced expression of defence genes in Arabidopsis thaliana infected with Phytophthora cinnamomi. Plant Pathology, 60, 1086-1095. doi: 10.1111/j.1365-3059.2011.02471.x

Fontenelle, A. D. B., Guzzo, S. D., Lucon, C. M. M., \& Harakava, R. (2011). Growth promotion and induction of resistance in tomato plant against Xanthomonas euvesicatoria and Alternaria solani by Trichoderma spp. Crop Protection, 30(11), 14921500. doi: 10.1016/j.cropro.2011.07.019

Freitas, M. B., \& Stadnik, M. J. (2012). Race-specific and ulvan-induced defense responses in bean (Phaseolus vulgaris) against Colletotrichum lindemuthianum. Physiological and Molecular Plant Pathology, 78, 8-13. doi: 10.1016/j.pmpp.2011.12.004

Gadaga, S. J. C., Abreu, M. S., Resende, M. L. V., \& Ribeiro, P. M., Jr. (2017). Phosphites for the control of anthracnose in common bean. Pesquisa Agropecuária Brasileira, 52(1), 36-44. doi: 10.1590/ S0100-204X2017000100005

Gill, S. S., \& Tuteja, N. (2010). Reactive oxygen species and antioxidant machinery in abiotic stress tolerance in crop plants. Plant Physiology and Biochemistry, 48(12), 909-930. doi: 10.1016/j.plaphy.2010.08.016

Gómez-Merino, F. G., \& Trejo-Téllez, L. I. (2015). Biostimulant activity of phosphite in horticulture. Scientia Horticulturae, 196(30), 82-90. doi: 10.1016/j.scienta.2015.09.035

Jwa, N. S., \& Hwang, B. K. (2017). Convergent evolution of pathogen effectors toward reactive oxygen species signaling networks in plants. Frontiers in Plant Science, 8(1687), 1-12. doi: 10.3389/fpls.2017.01687

Kumudini, B. S., Vasanthi, N. S., \& Shetty, H. S. (2001). Hypersensitive response, cell death and histochemical localization of hydrogen peroxide in host and non-host seedlings infected with the downy mildew pathogen Sclerospora graminicola. Annals of Applied Biology, 139(2), 217-225. doi: 10.111/ j.1744-7348.2001.tb00398.x

Melo, T. A., Araújo, M. U. P., Serra, I. M. R. S., \& Pascholati, S. F. (2017). Produtos naturais disponíveis comercialmente induzem o acúmulo de fitoalexinas em cotilédones de soja e mesocótilos de sorgo. Summa Phytopathologica, 43(3), 205-211. doi: 10.1590/0100-5405/167358

Niranjan Raj, A. S., Lavanya, A. S. N., Amruthesh, A. K. N., Niranjana, A. S. R., \& Reddy, B. H. S. (2012). Histo-chemical changes induced by PGPR during induction of resistance in pearl millet against downy mildew disease. Biological Control, 60(2), 90-102. doi: 10.1016/j.biocontrol.2011.10.011

Nojosa, G. B. R. A., Resende, M. L. V., Barguil, B. M., Moraes, S. R. G., \& Vilas Boas, C. H. (2009). Efeito de indutores de resistência em cafeeiro contra a mancha de Phoma. Summa Phytopathologica, 35(1), 60-62. doi: 10.159/S0100-54052009000100011

Nozaki, M. H., \& Kliemann, O. A. (2016). Avaliação do uso de fosfito no controle da antracnose em feijoeiro comum. Revista Agrarian, 9(31), 19-25. Recuperado de http://ojs.ufgd.edu.br/index.php/agrarian/article/ view/3076/3633

O’Connell, K. J., Bailey, J. A., \& Richmond, D. V. (1985). Cytology and physiology of infection of Phaseolus vulgaris by Colletotrichum lindemuthianum. Physiological Plant Pathology, 27(1), 75-98. doi: 10.1016/0048-4059(85)90058-X

Pedro, A. S., Harakava, R., Lucon, C. M. M., \& Guzzo, S. D. (2012). Promoção do crescimento do feijoeiro e controle da antracnose por Trichoderma spp. Pesquisa Agropecuária Brasileira, 47(11), 15891595. doi: 10.1590/S0100-204X2012001100005 
Saba, H., Vibhash, D., Manisha, M., Prashant, K. S., Farhan, H., \& Tauseef A. (2012). Trichoderma- a promising plant growth stimulator and biocontrol agent. Mycosphere, 3(4), 524-531. doi: 10.5943/ mycosphere/3/4/14

Statistical Analysis System Institute (2014). SAS University edition. Users Guide. Cary: SAS Institute INC.

Sewelam, N., Kazan, K., \& Schenk, P. M. (2016). Global plant stress signaling: reactive oxygen species at the cross-road. Frontiers in Plant Science, 7(187), 1-21. doi: 10.3389/fpls.2016.00187

Shaner, G., \& Finney, R. E. (1977). The effect of nitrogen fertilization on the expression of slow-mildewing resistence in knox wheat. Phytopathology, 67(8), 1051-1056. doi: 10.1094/Phyto-67-1051

Silva, H. F., Pinto, K. M. S., Nascimento, L. C., Silva, E. C., \& Souza, W. C. O. (2019). Avaliação do uso de elicitores de resistência bióticos e abióticos contra a antracnose na videira (Vitis labrusca L.). Summa Phytopathologica, 45(1), 70-75. doi: 10.1590/0100$5405 / 180414$

Silva, J. L., Souza, P. E., Alves, E., Pinto, J. E. B. P., Bertolucci, S. K. V., Freitas, M. L. O., \& Resende, M. L. V. (2015). Essential oil of Cymbopogon flexuosus, Vernonia polyanthes and potassium phosphite in control of bean anthracnose. Journal of Medicinal Plants Research, 9(8), 243-253. doi: 10.5897/ JMPR2014.5718

Silva, L. M., Alquini, Y., \& Cavallet, V. J. (2005). Interrelações entre a anatomia vegetal e a produção vegetal. Acta Botanica Brasílica, 19(1), 183-194. doi: $10.1590 / \mathrm{S} 0102-33062005000100018$

Singh, A., Shukla, N., Kabadwal, B. C., Tewari, A. K., \& Kumar, J. (2018). Review on plant-Trichodermapathogen interaction. International Journal of Current Microbiology and Applied Sciences, 7(2), 2382-2397. doi: 10.20546/ijcmas.2018.702.291

Soares, A. M. S., \& Machado, O. L. T. (2007). Defesa de plantas: sinalização química e espécies reativas de oxigênio. Revista Trópica: Ciências Agrárias e Biológicas, 1(1), 9-19. Recuperado de https:// www.academia.edu/6571798/Defesa_De_Plantas Sinalizacao_Quimica_EEspecies_Reativas_De_ Oxigenio_bio_Ar
Southerton, S. G., \& Deverall, B. J. (1990). Histochemical and chemical evidence for lignin accumulation during the expression of resistance to leaf rust fungi in wheat. Physiological and Molecular Plant Pathology, 36(6), 483-494. doi: 10.1016/08855765(90)90021-O

Stangarlin, J. R., Kuhn, O. J., Toledo, M. V., Portz, R. L., Schwan-Estrada, K. R. F., \& Pascholati, S. F. (2011). A defesa vegetal contra fitopatógenos. Scientia Agraria Paranaensis, 10(1), 18-46. doi: 10.1818/ sap.v10i1.5268

Stangarlin, J. R., Schulz, D. G., Franzener, G., Assi, L., Schwan-Estrada, K. R. F., \& Kuhn, O. J. (2010). Indução de fitoalexinas em soja e sorgo por preparações de Saccharomyces boulardii. Arquivos do Instituto Biológico, 77(1), 91-98. Recuperado de https://www.researchgate.net/ publication/324574822

Tavares, G. M., Laranjeira, D., Luz, E. D. M. N., Silva, T. R., Pirovani, C. P., Resende, M. L. V., \& Ribeiro, P. M., Jr. (2009). Indução de resistência do mamoeiro à podridão radicular por indutores bióticos e abióticos. Pesquisa Agropecuária Brasileira, 44(11), 14161423. doi: 10.1590/S0100-204X2009001100007

Thordal-Christensen, H., Zhang, Z., Wei, Y., \& Collinge, D. B. (1997). Subcellular localization of $\mathrm{H}_{2} \mathrm{O}_{2}$ in plants. $\mathrm{H}_{2} \mathrm{O}_{2}$ accumulation in papillae and hypersensitive response during the barley powdery mildew interaction. The Plant Journal, 11(6), 11871194. doi: 10.1046/j.1365-313X.1997.11061187.x

Walters, D. R., Ratsep, J., \& Havis, N. D. (2013). Controlling crop diseases using induced resistance: challenges for the future. Journal of Experimental Botany, 64(5), 1263-1280. doi: 10.1093/jxb/ert026

Zurbriggen, M. D., Carrillo, N., \& Hajirezaei, M. (2010). ROS signaling in the hypersensitive response. Plant Signaling and Behavior, 5(4), 393-396. doi: 10.4161/ psb.5.4.10793 
